\title{
$664399^{33}$ DP-994
}

AEC RESEARCH AND DEVELOPMENT REPORT

\section{IRRADIATION BEHAVIOR OF $\mathrm{Zr}-\mathrm{U}$ DRIVER TUBES FOR HWCTR}
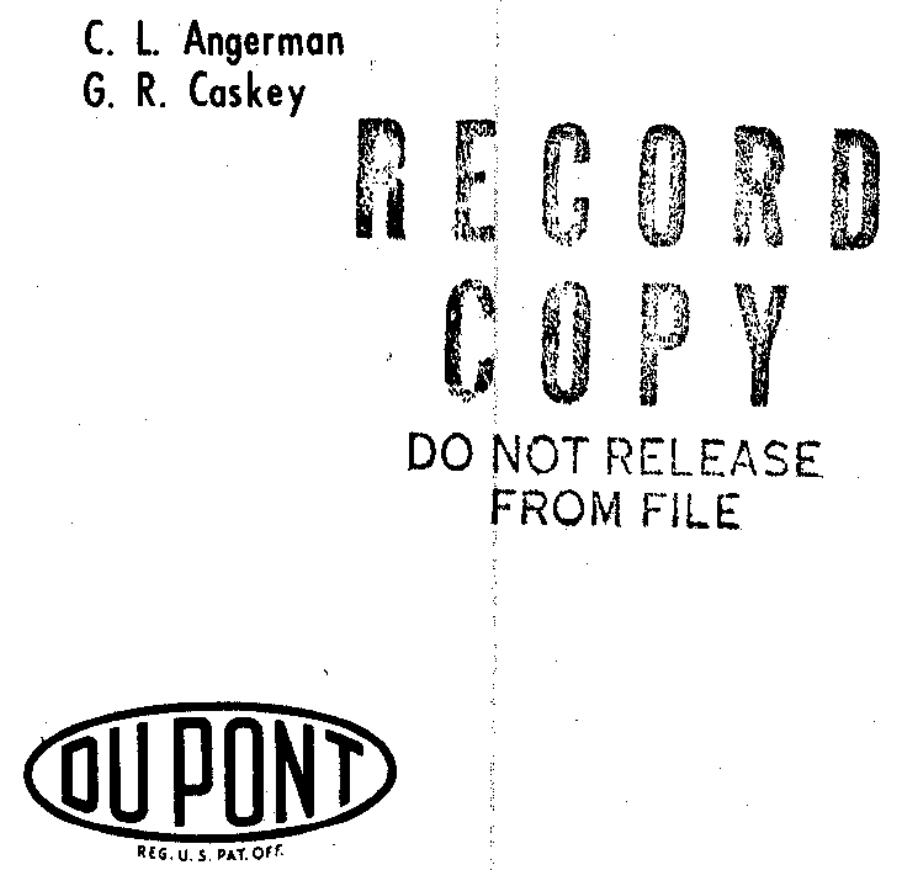

Savannah River Laboratory Aiken, South Carolina 


\section{LEGAL NOTICE}

This report was prepared as an account of Government sponsored work. Neither the United States, nor the Commission, nor any person acting on behalf of the Commission:

A. Makes any warranty or representation, expressed or Implied, with respect to the accuracy, completeness, or usefulness of the information contained in this report, or that the use of any information, apparatus, method, or process disclosed in this report may not infringe privately owned rights; or

B. Assumes any liabllities with respect to the use of, or for damages resulting from the use of any information, apparatus, method, or process disolosed in this report.

As used in the above, "person acting on behalf of the Commission" Includes any employee or contractor of the Commission, or employee of such contractor, to the extent that such employee or contractor of the Commisaion, or employee of such contractor prepares, disseminates, or provides access to, any information pursuant to his employment or contract with the Commission, or his employment with such contractor.

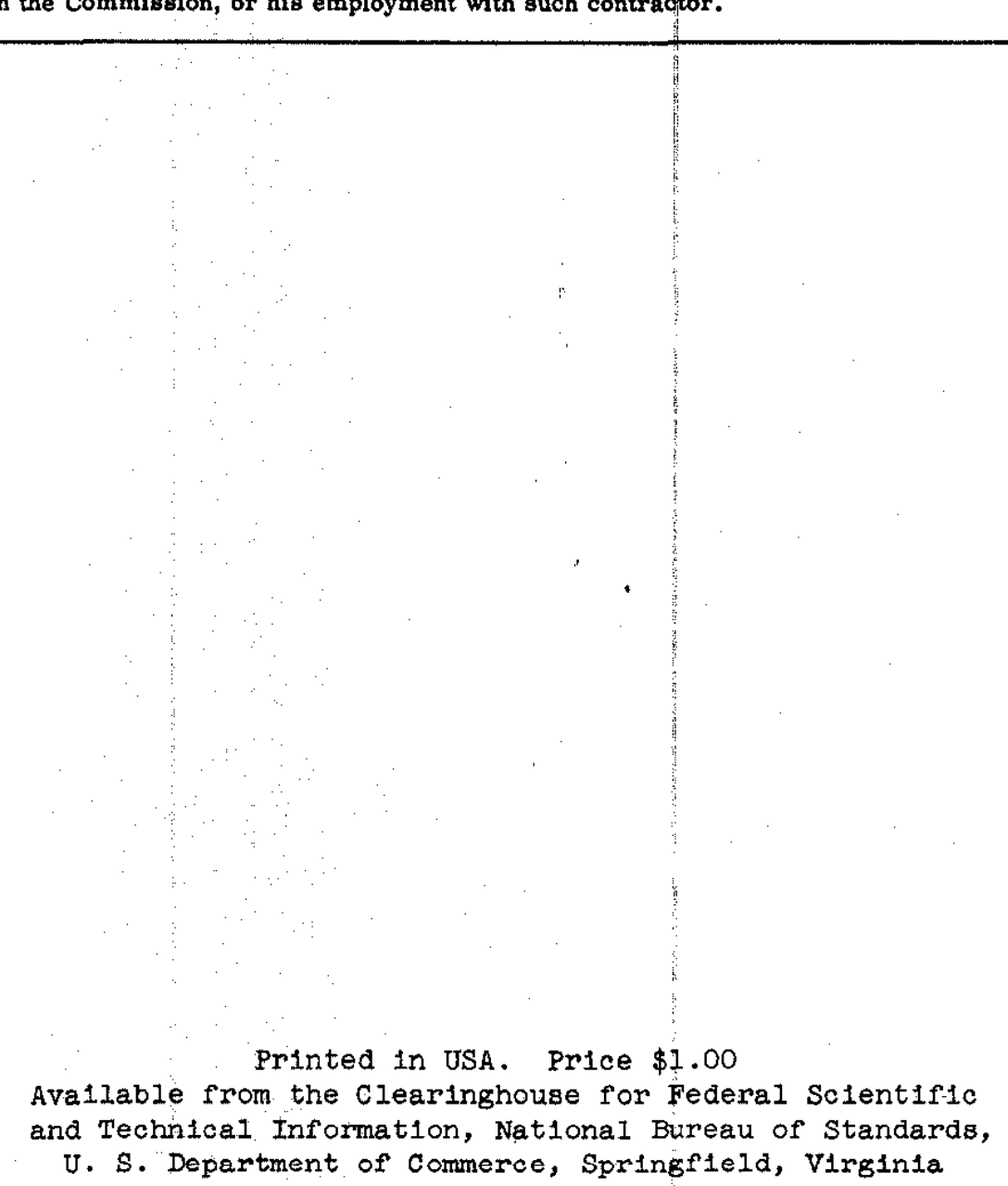


E. I. DU PONT de Nemours \& COMPany

C. W. J. WENDE, DIRECTOR TECHNICAL DIVISION - AED EXPLOSIVES DEPARTMENT WILMINGTON

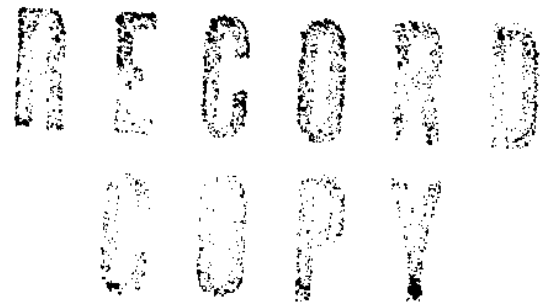

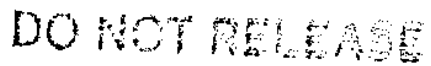

FROM Hin

$$
\begin{aligned}
& \text { DP-994, IRRADIATION BEHAVIOR OF } \\
& \text { by C. L. Angerman and G. R. Caskey, Jr. }
\end{aligned}
$$

This report summarizes the postirradiation measurement and metallographic examination of the HWCTR driver tubes, performed by the Reactor Engineering and Nuclear Materials Divisions. The driver tube performance was better than had been anticipated, under relatively severe irradiation conditions.

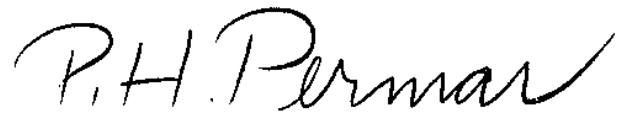

P. H. Permar, Research Manager Nuclear Materials Division 


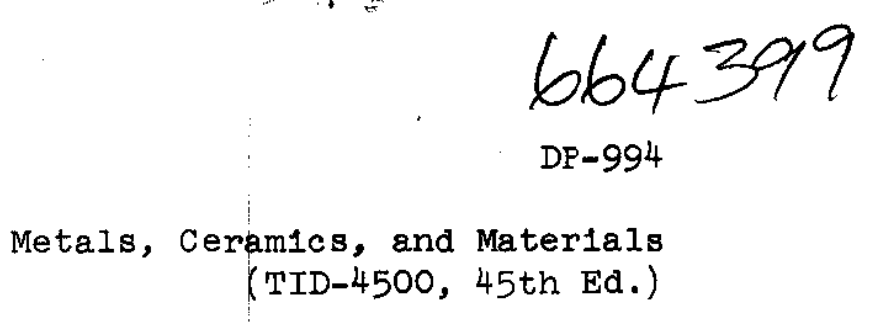

IRRADIATION BEHAVIOR OF $Z r-U$ DRIVER TUBES FOR HWCTR

by

Carl L. Angerman and George R. Caskey, Jr.

Work done by

C. L. Angerman

F. C. Locke

G. R. Caskey, Jr.

W. R. McDonell

M. Hendrix

M. A. Post

A. F. Wright

Approved by

P. H. Permar, Research Manager Nuclear Materials Division

October 1965

E. I. DU PONT DE NEMOURS \& COMPANY

SAVANNAH RIVER LABORATORY

AIKEN, SOUTH CAROLINA

CONTRACT AT(07-2)-I WITH THE

UNITED STATES ATOMIC ENERGY COMMISSION 


\begin{abstract}
The HWCTR was fueled with enrlched urantum tubes of $\mathrm{Zr}-9.3$ wt $\% \mathrm{U}$ alloy clad with Z1rcaloy-2 by coextrusion. Irradiation of these tubes up to 1.83 atom $\%$ burnup at temperatures up to $540^{\circ} \mathrm{C}$ and under 1200 ps 1 coolant pressure resulted in volume increases up to $5 \%$, only about half of the amount predicted by published data. The volume increases were caused by the formation of sol1d fission products and the precipltation of fission gases in small bubbles.
\end{abstract}




\section{CONTENTS}

$\begin{array}{lr}\text { Introduction } & \frac{\text { Page }}{\text { Summary }} \\ \text { Discussion } & 5 \\ \quad \text { Fabrication } & 5 \\ \quad \text { Irradiation } & 6 \\ \text { Sweliling During Irradiation } & 6 \\ \quad \text { Microstructural Changes During Irradiation } & 6 \\ \quad \text { Effect of Postirradiation Annealing } & 8 \\ \text { Bibliography } & 9\end{array}$

\section{LIST OF TABLES AND FIGURES}

$\underline{\text { Table }}$

I Irradiation Conditions and Behavior of Driver Tubes

Figure

1 Zirconium-Uranlum Phase Diagram 10

2 Microstructure of As-Extruded $\mathrm{Zr}-9.3$ wt $\%$ U Alloy 10

3 Proflles of T1me-Averaged Central Metal Temperature 11

4 Dimensional Change and Exposure Profiles, Tube $22 \quad 12$

5 Dimensional Change and Exposure Profiles, Tube $48 \quad 13$

6 Dimensional Change and Exposure Profiles, Tube $1 \quad 14$

7 Dimensional Change and Exposure Profiles, Tube $18 \quad 15$

8 Comparison of Swelling Behavior of HWCTR Driver Tubes with Previously Published Irradiation Data 16

9 Fission Gas Bubbles Formed During Irradiation 17

10 Distortion of $\epsilon$ Phase During Irradiation 17

11 Typical Microstructure of Irradiated Zircaloy-2

12 Gas Bubbles Produced by Postirradiation Annealing 18 



\section{IRRADIATION BEHAVIOR OF $\mathrm{Zr}-U$ DRIVER TUBES FOR HWCTR .}

\section{INTRODUCTION}

The Heavy Water Components Test Reactor (HWCTR) was designed for the irradiation testing of full-size prototype fuel assemblies of uranium metal or uranium oxlde for potential use in heavy-watermoderated and -cooled power reactors. (1) The reactor itself was fueled with 2.3-1nch-diameter enriched uranlum "driver" tubes of $\mathrm{Zr}$ 9.3 wt $\%$ U clad with Zircaloy by coextrusion. (2) These tubes normally operated at central temperatures of $500-540^{\circ} \mathrm{C}$ and $1000-1200 \mathrm{ps} 1$ system pressure to total atom burnups of 1.5-2.0\%. Published data on the irradiation behavior of small samples of $\mathrm{Zr}$ alloys containing 6 to 22 wt \% U indicated that volume increases as high $2810 \%$ might be anticipated under these conditions. $(3,4)$

Since only a limited amount of swelling could be tolerated and there were no data avallable on the performance of large fuel elements of this type, four of the driver tubes were measured at intervals durlng irradiation to monitor their swelling behavior. A detalled postirradiation examination was conducted to determine the cause of swelling, and postirradiation annealing experiments were performed to characterize the sweling that might occur at higher irradiation temperatures.

SUMMARY

Irradiation of the driver tubes up to 1.83 atom \% burnup at timeaveraged central metal temperatures up to $540^{\circ} \mathrm{C}$ and under $1200 \mathrm{ps}$ coolant pressure resulted in volume increases up to $5.1 \%$, which was less swelling than anticipated. Th1s swelling occurred as an increase In wall thickness and was caused princlpally by the formation of solld fission products, with a lesser contribution due to precipitation of flssion gases in small bubbles. The reactor pressurization, as well as impurities in the cores, may have limited the fission gas swelling. Much larger volume increases occurred during postirradiation annealing for 74 hours at $600^{\circ} \mathrm{C}$ under low external restraint.

The irradiation had no visible effect on the zircaloy-2 cladding. Negligible corrosion of the cladding by the heavy water coolant occurred, as indicated by the absence of hydride precipitates in the cladding. The circumferential strain in the cladding due to the swelling of the core was less than $0.3 \%$. 


\section{DISCUSSION}

\section{FABRICATION}

The dr1ver tubes, 2.30-1nch OD by 1.96-inch ID clad w1th 0.015 inch of Zircaloy-2, were fabricated by coextrusion by Nuclear Metals, Inc. (2) Vacuum-induction-melted alloy of $\mathrm{Zr}-9.3$ wt $\%$ was cast. Into graphite molds and machined to form cores for the coextrusion b1liet. The carbon content of the core was less than $2500 \mathrm{ppm}$. Billets were heated to $690^{\circ} \mathrm{C}$ and extruded. After extrusion the tubes were straightened, etched, and autoclaved 4 hours at $340^{\circ} \mathrm{C}$ in water and 4 hours at $400^{\circ} \mathrm{C}(1500 \mathrm{ps} 1)$ steam.

At the extrusion temperature, the alloy is a two-phase mixture of alpha $(\alpha) \mathrm{Zr}$ and gamma $(\gamma)$ solid solution of $\mathrm{Zr}$ with 13 atom $\% \mathrm{U}$ (Figure 1). Since the tubes were not heat treated after extrusion, except for autoclaving, the microstructure before irradiation was a finely divided lameliar array of epsilon ( $\epsilon$ ) phase particles within a matrix of $\alpha-\mathrm{Zr}$ (F1gure 2). The $\epsilon$ forms from $\gamma$ by a eutecto1d decomposition.

\section{IRRADIATION}

In the HWCTR, the driver tubes were arranged in a ring with positions for testing of experimental fuel elements within this ring. The operation of the reactor was divided into two different cycles; new driver tubes were charged at the start of the second cycle. The second cycle was operated at higher nominal temperatures than the first. In the first cycle, the nominal operating conditions for the driver tubes were $540^{\circ} \mathrm{C}$ maximum core temperature $\left(510^{\circ} \mathrm{C}\right.$ time-averaged), $1200 \mathrm{ps} 1$ system pressure, and 1.83 atom of calculated maximum burnup; during the second cycle of operation, the conditions were $585^{\circ} \mathrm{C}$ maximum core temperature $\left(540^{\circ} \mathrm{C}\right.$ time-averaged), 1200 ps1 system pressure, and 1.54 atom $\%$ calculated maximum burnup. Surface temperatures of the Zircaloy2 cladding were as high as $306^{\circ} \mathrm{C}$ in the second cycle. Temperature profiles along the lengths of the four tubes that were inspected are shown in Figure 3.

\section{SWELLING DURING IRRADIATION}

The two tubes that operated at the highest temperatures were chosen from each cycle for interim inspection during the course of Irradiation. Measurements of outside and inslde diameters, made perlodicaliy in a disassembly basin at several locations along the lengths of the tubes, Indicated that up to $3.6 \%$ sweling had occurred. The final dimensional and volume changes (changes in cross-sectional area) and exposure profiles for the tubes are shown in Figures 4 through 7 . 
The pertinent data from the interim inspections, corrected for systematic errors, are summarlzed in Table I. Some corrections were needed, because volume decreases of 1 to $3 \%$ were actually indlcated at the ends of the tubes where the exposures and temperatures were low. Furthermore, the volume increases calculated from measurements of the outside diameter and wall thickness on individual ring sections cut from the tubes for subsequent metallographic examination were several percentage points greater than the increases calculated from the measurements made in the disassembly basin. Since these data indicate that a systematic error was present in the original measurements, all the volume data were adjusted to extrapolate to zero at zero burnup for subsequent discussions. These adjusted values are shown in parentheses in Table I.

\section{TABLE I}

Irradiation Conditions and Behavior of Driver Tubes

\begin{tabular}{|c|c|c|c|c|c|c|c|c|c|}
\hline \multirow[b]{2}{*}{$\begin{array}{c}\text { Cycle } \\
\text { No. }\end{array}$} & \multirow[b]{2}{*}{$\begin{array}{l}\text { Tube } \\
\text { No. }\end{array}$} & \multicolumn{3}{|c|}{ Irradiation Conditions } & \multicolumn{5}{|c|}{ Max. Dimensional Changes (c) } \\
\hline & & $\begin{array}{l}\text { Calc. } \\
\text { Burnup, } \\
\text { atom }\end{array}$ & $\begin{array}{c}\text { TACMT }(a), \\
{ }^{\circ} \mathrm{C} \\
\end{array}$ & $\begin{array}{c}\operatorname{Max} \operatorname{CMr}^{(b)}, \\
{ }^{\circ} \mathrm{C} \\
\end{array}$ & $\begin{array}{l}\triangle \mathrm{OD}, \\
\mathrm{m11 \textrm {s }}\end{array}$ & $\begin{array}{l}\text { Cladding } \\
\text { Stra1n, } \%\end{array}$ & $\begin{array}{r}\Delta I D, \\
\text { mIIB } \\
\end{array}$ & $\begin{array}{c}\Delta v / N, \\
\end{array}$ & $\begin{array}{c}R^{(d)} \\
\text { o/atom os }\end{array}$ \\
\hline \multirow[t]{2}{*}{1} & 48 & 1.47 & 486 & 536 & 4 & 0.18 & -10 & $\begin{array}{l}3.6 \\
(5.1)\end{array}$ & 3.4 \\
\hline & & 1.80 & 489 & 532 & 2 & 0.10 & -11 & $\begin{array}{c}3.2 \\
(4.7)\end{array}$ & 2.6 \\
\hline \multirow[t]{3}{*}{1} & 22 & 1.18 & 501 & 531 & 3 & 0.13 & -6 & $\begin{array}{c}2.5 \\
(4.0)\end{array}$ & 3.4 \\
\hline & & 1.57 & 502 & 530 & 5 & 0.22 & -8 & $\begin{array}{c}3.2 \\
(4.7)\end{array}$ & 3.0 \\
\hline & & 1.83 & 508 & 528 & 5 & 0.17 & -8 & $\begin{array}{c}3.4 \\
(4.9)\end{array}$ & 2.7 \\
\hline \multirow[t]{4}{*}{2} & 1 & 0.32 & 533 & 539 & -1 & 0 & -2 & 0.22 & 0.7 \\
\hline & & 0.76 & 534 & 569 & 2 & 0.09 & -7 & $\begin{array}{r}2.75 \\
(2.3)\end{array}$ & 3.0 \\
\hline & & 1.33 & 522 & 565 & -1 & 0 & -6 & $\begin{array}{r}1.16 \\
(3.2)\end{array}$ & 2.4 \\
\hline & & 1.50 & 530 & 526 & $\frac{1}{(5)} *$ & $\begin{array}{c}0.02 \\
(0.17) *\end{array}$ & $\left(\begin{array}{c}-4 \\
(-14) *\end{array}\right.$ & $\begin{array}{c}0.8 \\
(4.3) *\end{array}$ & 2.9 \\
\hline \multirow[t]{4}{*}{2} & 18 & 0.32 & 523 & 539 & 0 & 0.15 & -4 & 1.09 & 3.4 \\
\hline & & 0.79 & 543 & 585 & 0 & 0.28 & -7 & $\begin{array}{r}2.04 \\
(1.5)\end{array}$ & 1.9 \\
\hline & & $1.3^{8}$ & 534 & 572 & 1 & 0.08 & -5 & $\begin{array}{l}1.96 \\
(4.3)\end{array}$ & 3.1 \\
\hline & & 1.54 & 538 & 509 & $\stackrel{1}{(7) *}$ & $\begin{array}{c}0.03 \\
(0.27) *\end{array}$ & $\begin{array}{l}-2 \\
(-9) *\end{array}$ & $\begin{array}{c}0.56 \\
(4.1)^{*}\end{array}$ & 2.7 \\
\hline
\end{tabular}

(a) Time-averaged central metal temperature.

(b) Maximum central metal temperature during irradiation.

(c) Where two sets of values are given, the values in parentheses have been adjusted so that the change in volume extrapolates to zero at zero exposure; the others are raw data obtained from measurements made on fulilength tubes in the basin.

(a) Swelling rate - percent increase in volume per atom percent burnup.

* The data marked with an asterlsk are based on direct measurements made on ring sections in a hot cell. 
Inspection of the data on changes in outslde and inside diameters indicated that the volume change was caused by an increase in wall thickness. The inside diameter decreased more than the outside diameter increased. Correspondingly, circumferential tensile strain in the outer Zircaloy-2 cladding was low, less than $0.3 \%$. The average diameter decreased about $0.2 \%$ and the lensth increased about $0.5 \%$, Indicating some slight anisotropic growth. Hexagonal metals, such as zirconium, w1ll grow when irradiated with fission fragments. '5)

The behavior of these $\mathrm{Zr}-\mathrm{U}$ alloy tubes was distinctly better than anticipated. Avallable swelling data from the literature, derived from Irradiation tests on small samples, predict volume increases of up to $10 \%$, or about twice the observed swelling for the temperatures and exposures that prevalied during the irradiation. 13,4$)$ The behavior of the HWCTR driver tubes is compared to the published data in Figure 8. The improved behavior was attributed to the smaller contribution of flssion gas swelling in the drivers than in the small samples. Reactor pressurization, as well as impurities in the cores, may have restricted the agglomeration of the fission gases.

In some cases the HWCTR driver tubes stuck in their housing tubes after 1rradiation; however the tubes were easily removed w1th a small force. Such sticking would be expected, since a volume increase of about $4 \%$ would eliminate the clearance between the driver and housing; as shown in Table I, volume increases of as much as $5.1 \%$ were observed.

\section{MICROSTRUCTURAL CHANGES DURING IRRADIATION}

Specimens were cut for metallographic examination from the hottest position (maximum swelling) in each tube; specimens were also cut from near the ends of Tubes 22 and 48 . The principal microstructural features were:

- Fission gas bubbles were observed in specimens irradiated at 490 to $540^{\circ} \mathrm{C}$, but none were observed in the specimens irradiated at $400^{\circ} \mathrm{C}$.

- Fission gas bubbles were often more prevalent along the $\alpha-\epsilon$ interface than within the $\alpha$ phase.

- The $\epsilon$ phase particles were slightly distorted and spheroldized as compared to those in the as-extruded tube where the pattern was more regular and lamellar.

- No cracks were observed in either the core or cladding. 
- No hydride or twins were seen in the zircaloy cladding of the specimens from elther high- or low-temperature regions of the tube.

Fission gas bubbles up to 0.4 micron in diameter were present in specimens Irradiated at 490 to $540^{\circ} \mathrm{C}$ (Figure 9), but none were present in the specimens 1rradiated at $400^{\circ} \mathrm{C}$. Volume increases due to the gas bubbles, calculated from measurements of bubble diameters and concentrations, ranged up to $2.1 \%$, which when added to the 1ncrease due to solid fission products, $2.5 \%$ per atom \% burnup, essentlally accounted for the observed volume increases. Bubbles were somet1mes located along the $\alpha-\epsilon$ interface as well as throughout the $\alpha-z 1$ rconium. No bubbles could be positively identified within the $\epsilon$ phase in spite of its much higher uranium concentration.

Some distortion and spheroldization of the $\epsilon$ phase were evident, although these were not as pronounced as in $U-2$ wt $\% \mathrm{Zr}$ alloys. (o) The difference between the two cases is probably due to the much greater irradiation growth in the case of the $\alpha$-uranium matrix in the $U-2$ wt of $\mathrm{Zr}$ alloy. The a-zirconium has a much lower growth rate and hence would distort less and not break up the $\epsilon$ phase pattern generated by extrusion. Distortion was more pronounced in the higher temperature portion of the tube in keeping with the greater exposure and growth in that region (Figure 10).

Cladding corrosion during reactor operation was negligible as judged by the absence of hydride in the cladding. No hydride was seen in any of the sections. Absence of twins in the cladding was in keeping with the very low cladding strains that were measured (Figure 11).

\section{EFFECT OF POSTIRRADIATION ANNEALING}

Operation of the drivers at maximum core temperatures of $600^{\circ} \mathrm{C}$ would generate a higher flux for Irradiation of the test fuel in the HWCTR. In order to obtain an indication of the maximum swelling that might occur during irradiation at a temperature within the $a+\gamma$ region, a specimen from Tube 22 (Irradiated at $500^{\circ} \mathrm{C}$ ) was annealed at $600 \pm 4{ }^{\circ} \mathrm{C}$ for 2 hours, examined metallographically, annealed an additional 72 hours and re-examined. In contrast to irradiation, only low external restraint (due to the cladding) was present during the postirradiation anneals. The increases in volume of the specimen during annealing, based on pre- and post-annealing density measurements, was $10.4 \%$ after 2 hours of annealing and a total of $21.0 \%$ after 74 hours of annealing. Increases in the sizes and concentrations of gas bubbles accounted for this swelling, as shown in Figure 12. The volume increase after 74 hours is about twice as much as observed by Johnston (7), but the burnup was somewhat higher, 1.8 compared to 1.15 atom $\%$. 


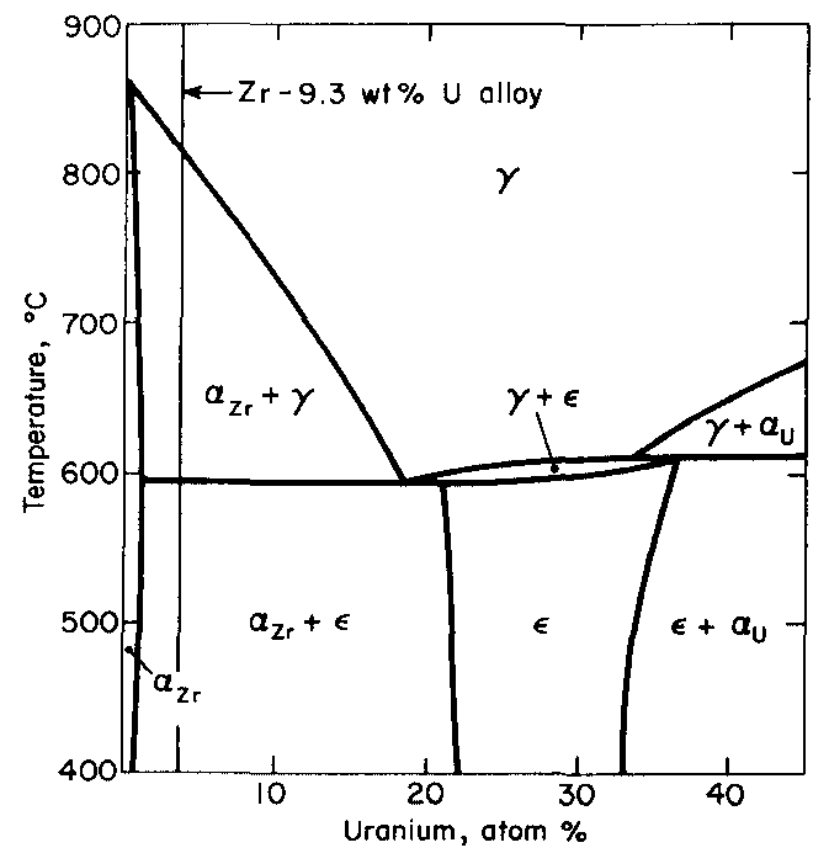

FIG. I ZIRCONIUM-URANIUM PHASE DIAGRAM

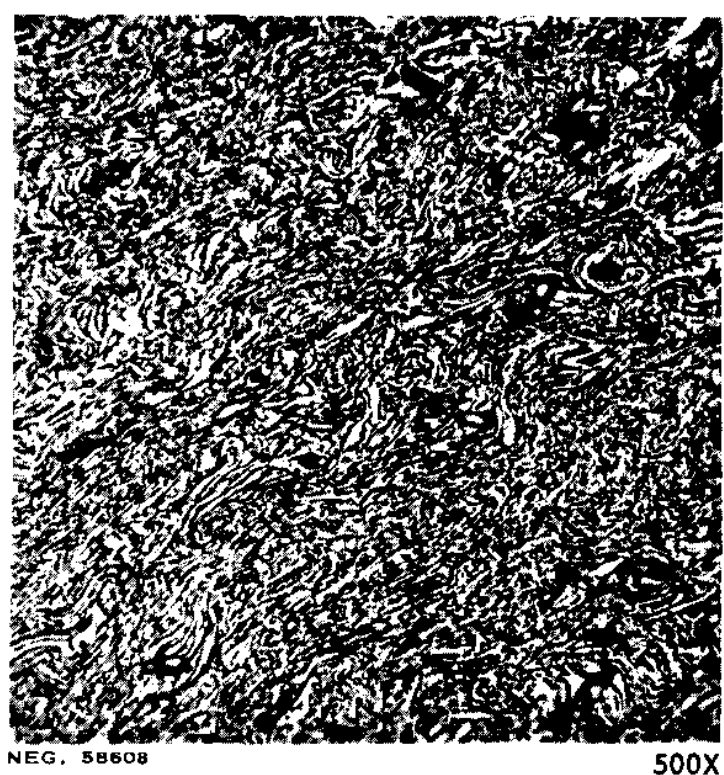

a. Optical micrography showing distorted pattern of finely divided $a$ and $\epsilon$ phases.

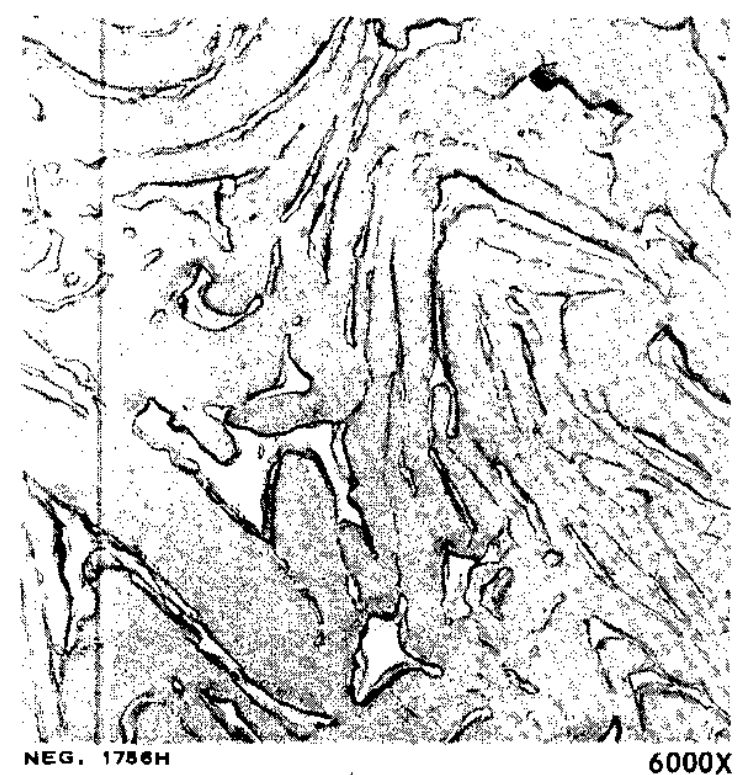

b. Electron microgroph showing both lamellar and massive $\epsilon$ particles.

FIG. 2 MICROSTRUCTURE OF AS-EXTRUDED $\mathrm{Zr}-9.3$ wt $\%$ U ALLOY 


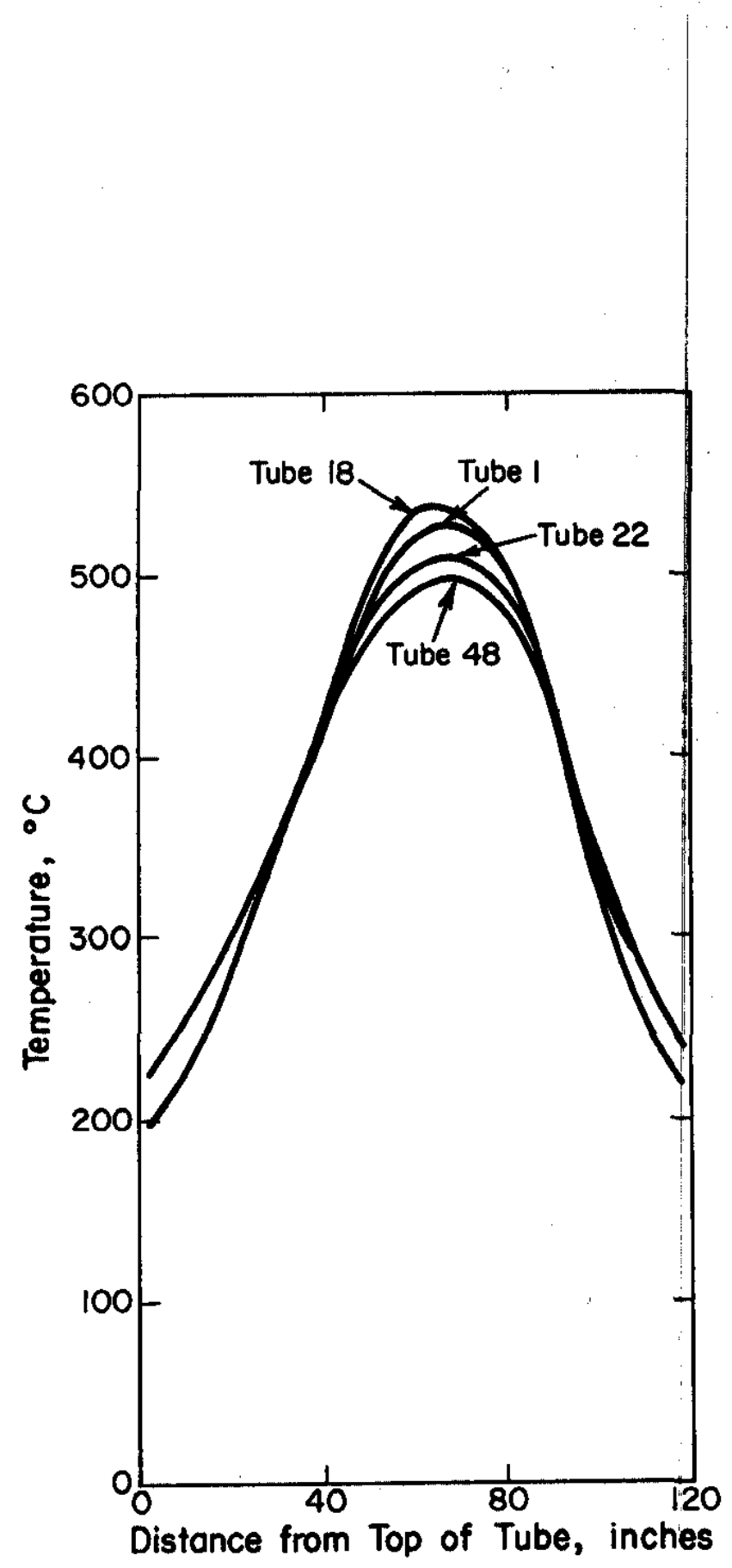

FIG. 3 PROFILES OF time-AVERAged Central metal temperature 

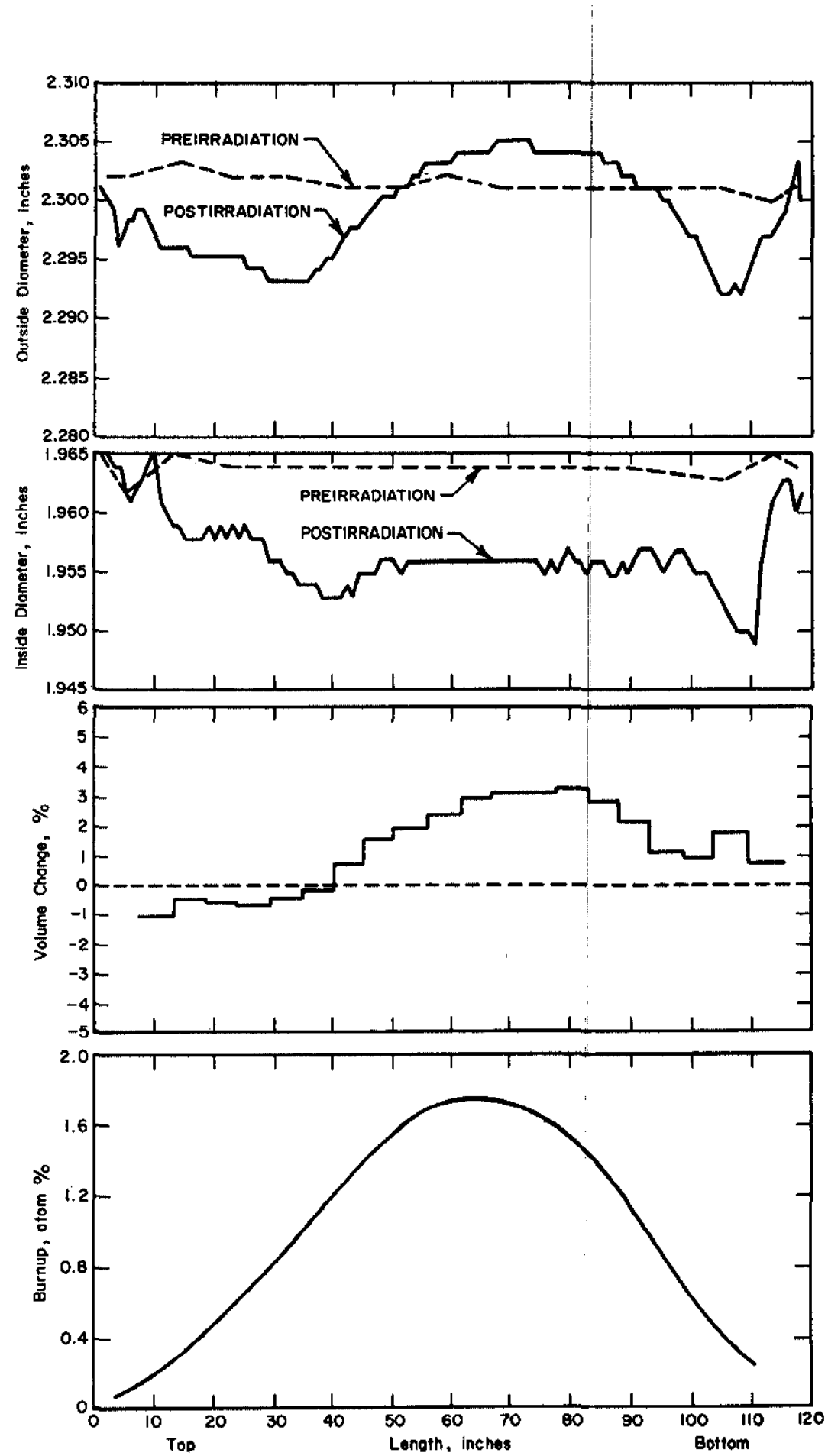

FIG. 4 DIMENSIONAL CHANGE AND EXPOSURE PROFILES, TUBE 22 

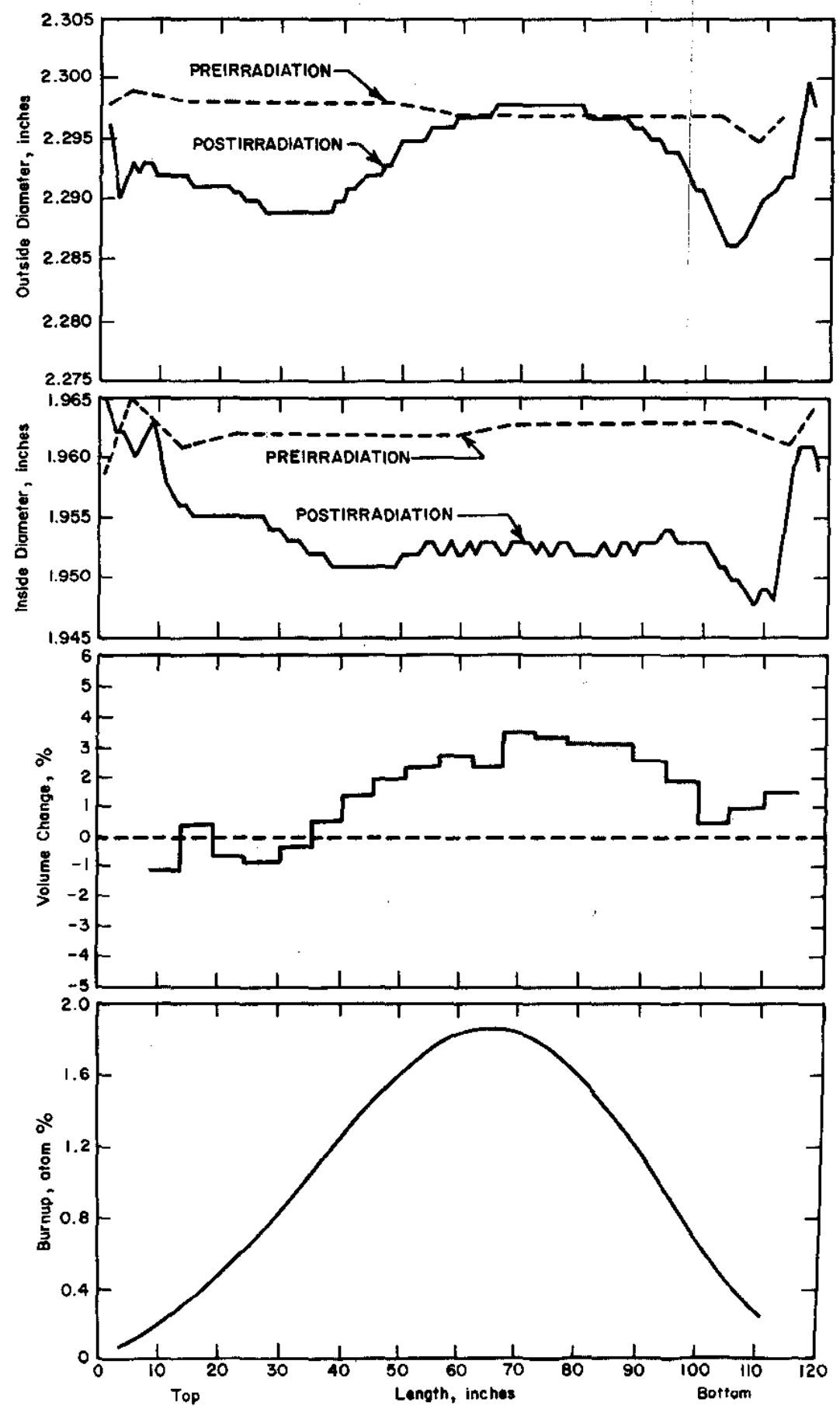

Fig. 5 DIMENSIONAL Change AND EXPOSURE PROFILes, tube 48 

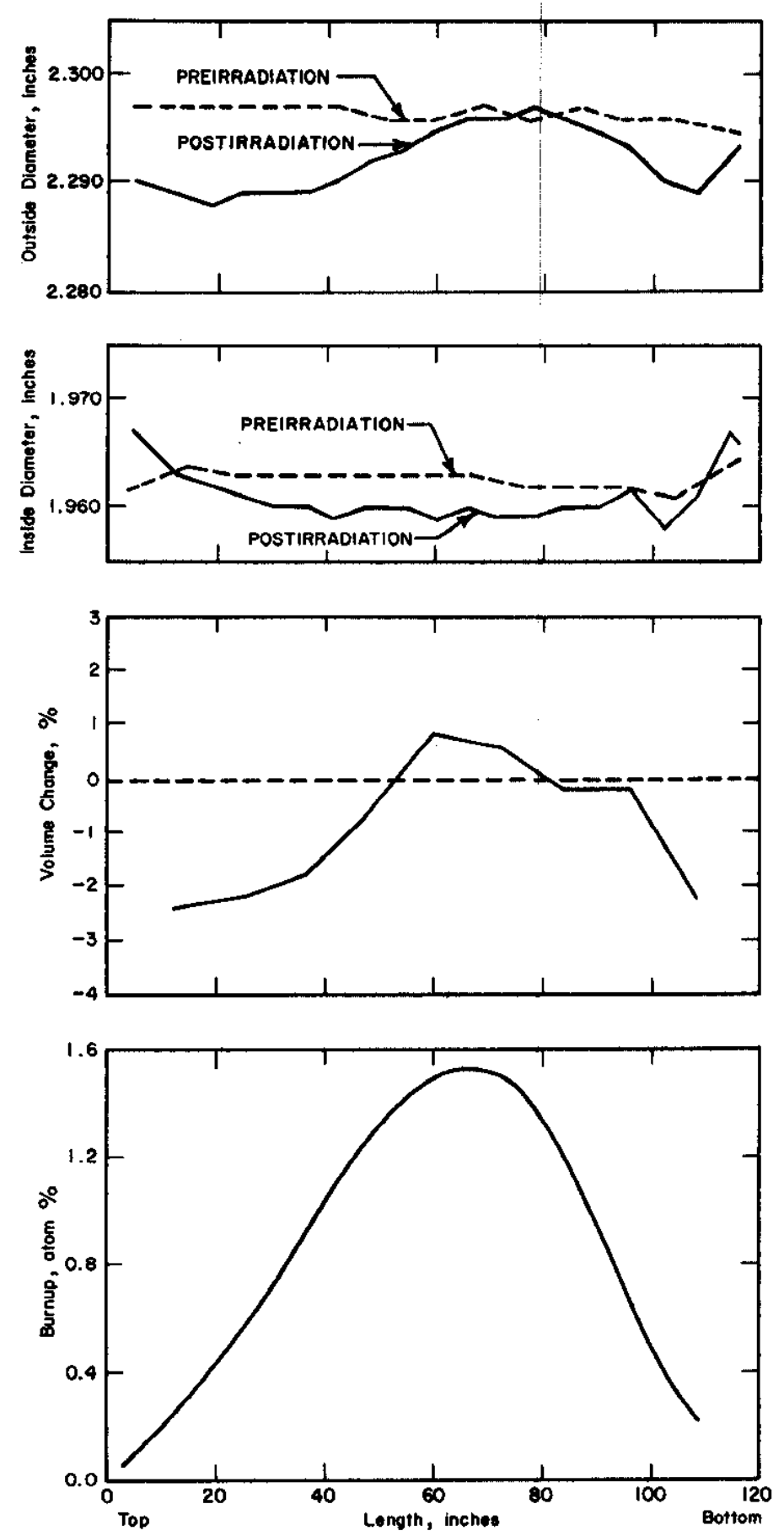

Fig. 6 dimensional Change and exposure profiles, tUBE 1 

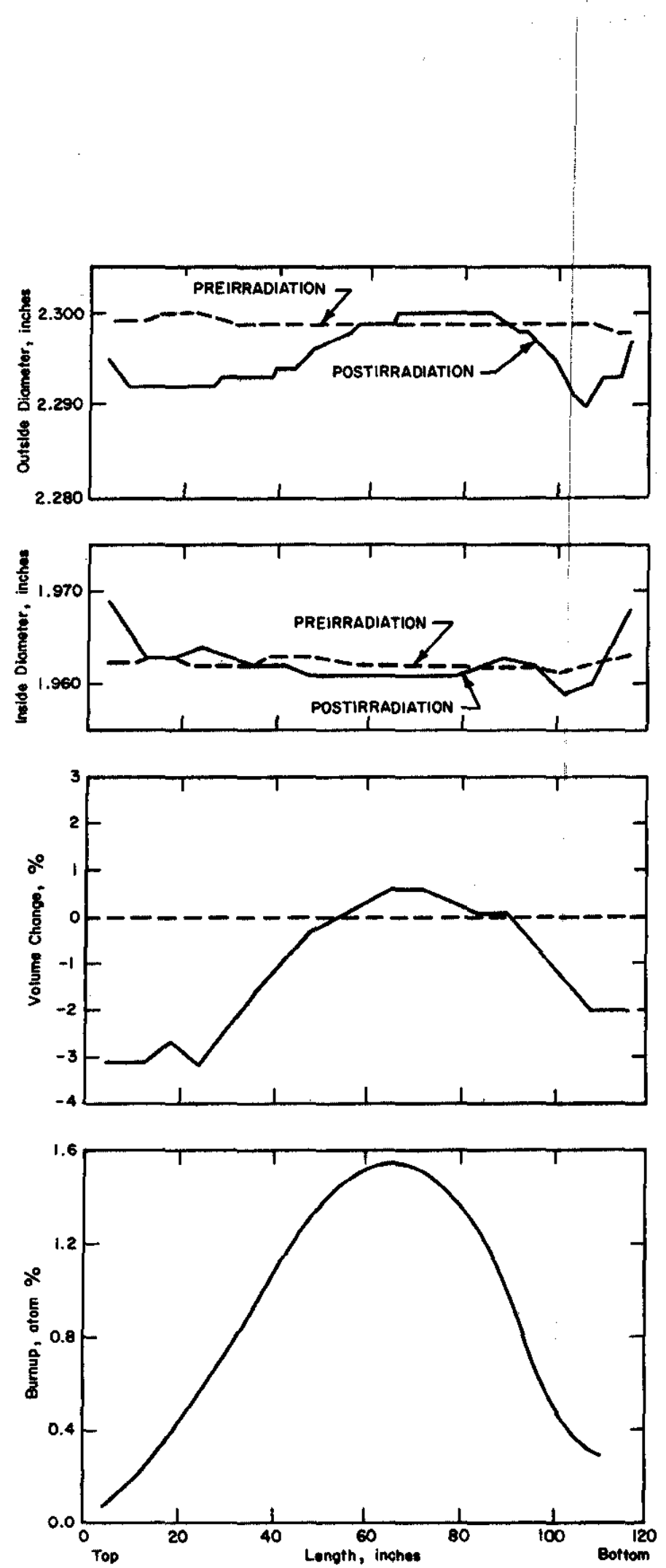

FIG. 7 DIMENSIONAL CHANGE ANE EXPOSURE PROFILES, TUBE 18 


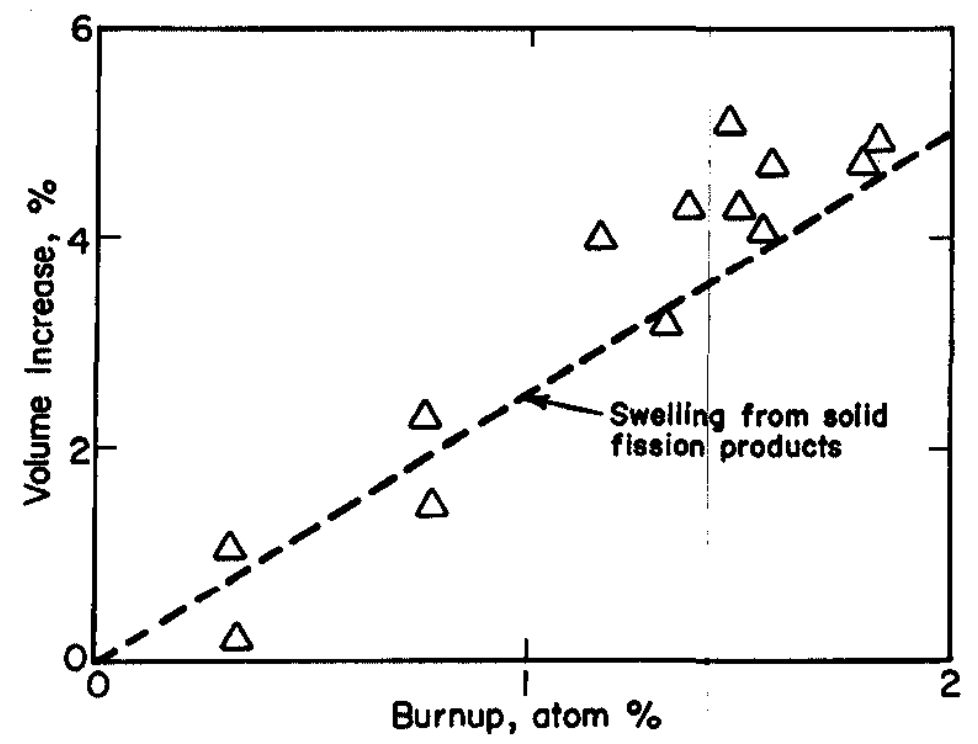

a. Variation in swelling with burnup for HWCTR tubes. Dota may be represented by a linear relationship, although some departure may be indicated at the higher burnups and temperatures.

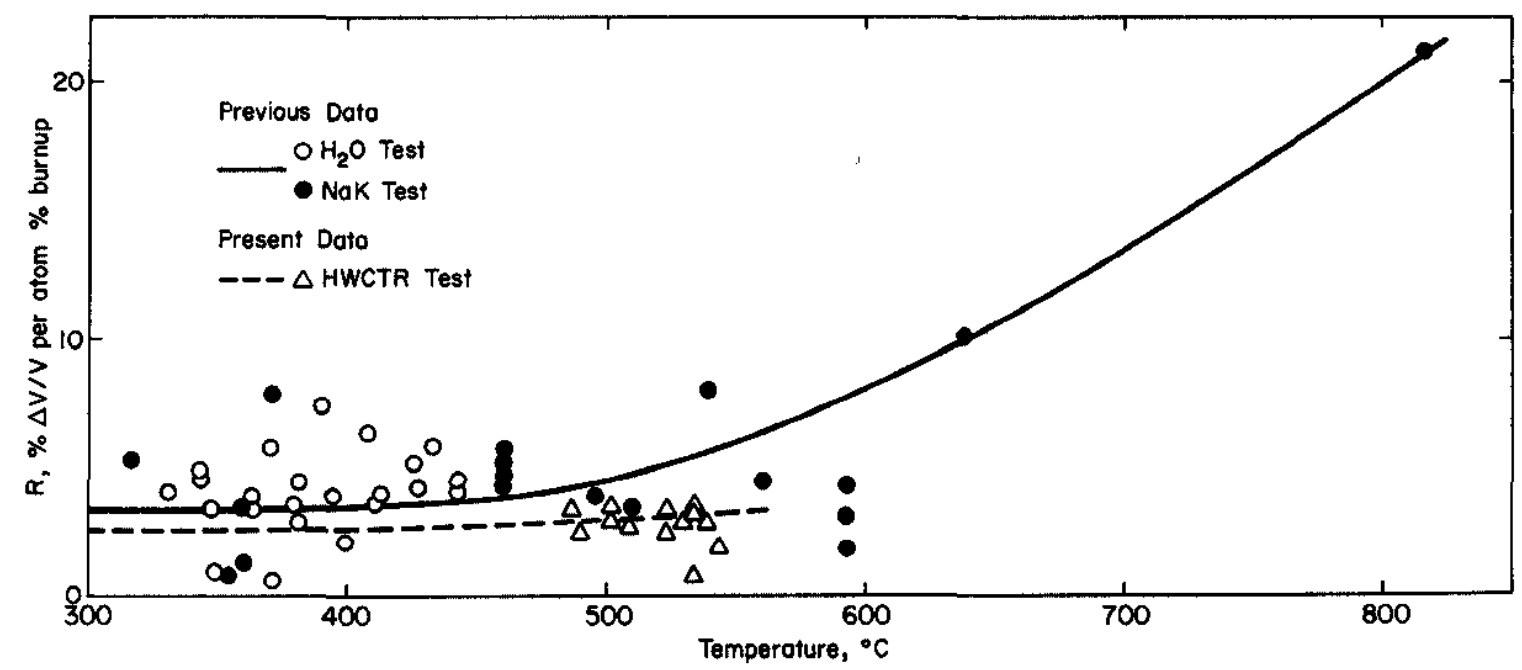

b. Voriation of normalized swelling, $R$, with temperature.

FIG. 8 COMPARISON OF SWELLING BEHAVIOR OF HWCTR DRIVER TUBES WITH PREVIOUSLY PUBLISHED IRRADIATION DATA $(3,4)$ 


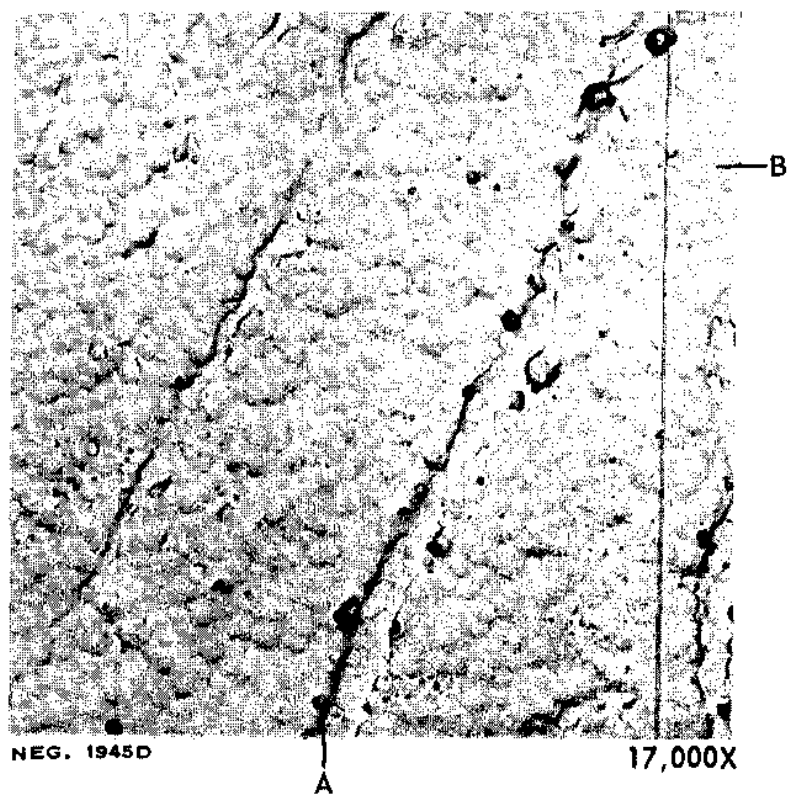

Fission gas bubbles (A) along interface between $a$ and $\epsilon$ phases and $(B)$ in the $a$-zirconium matrix. Exposure $=1.89$ atom \% burnup, temperature $=500^{\circ} \mathrm{C}$.

FIG. 9 FISSION GAS BUBBLES FORMED DURING IRRADIATION

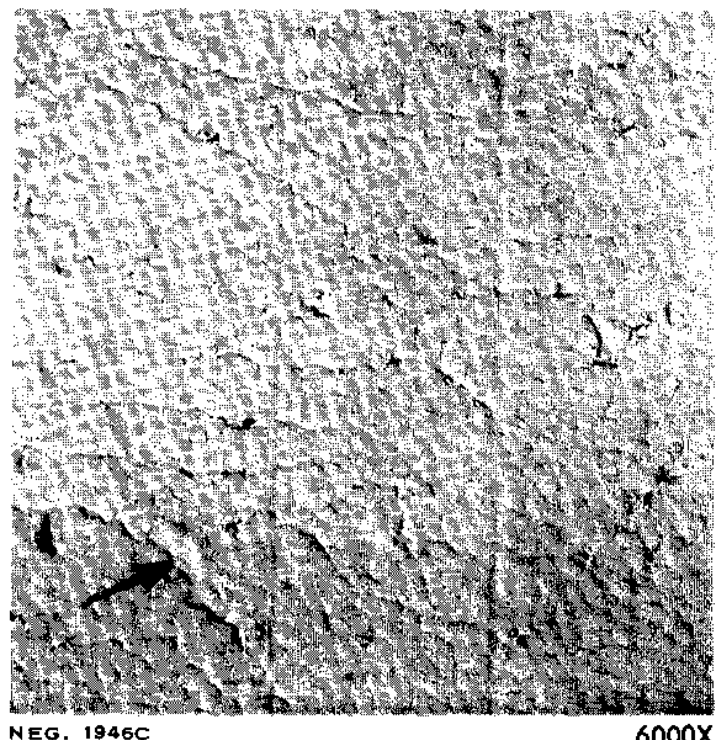

a. Region of alloy irradiated at $400^{\circ} \mathrm{C}$ to 1.10 atom $\%$ burnup. Pattern of $\epsilon$ phase altered very little from that of as - extruded alloy (compare Figure 2b).

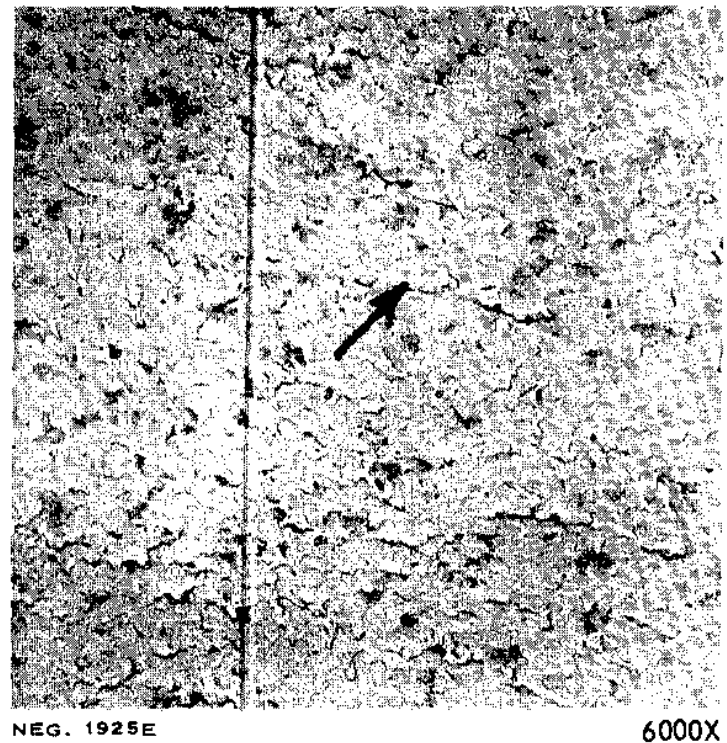

b. Region of alloy irradiated at $485^{\circ} \mathrm{C}$ to 1.80 atom $\%$ burnup showing distorted patiern of $\epsilon$ phase.

FIG. 10 DISTORTION OF $€$ PHASE DURING IRRADIATION 


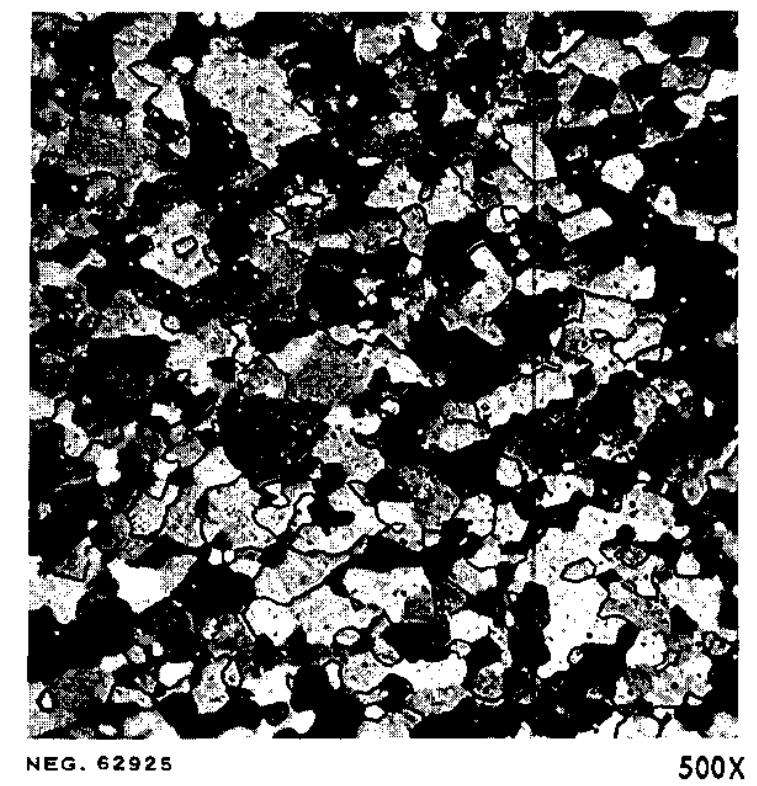

FIG. 11 TYPICAL MICROSTRUCTURE OF IRRADIATED ZIRCALOY-2 CLADDING No twins or zirconium hydride particles

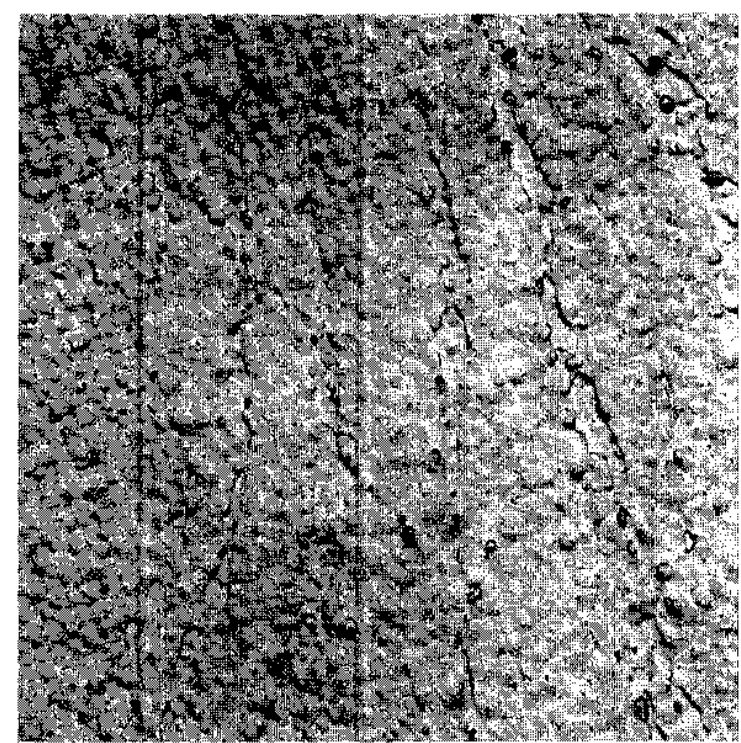

$6000 x$

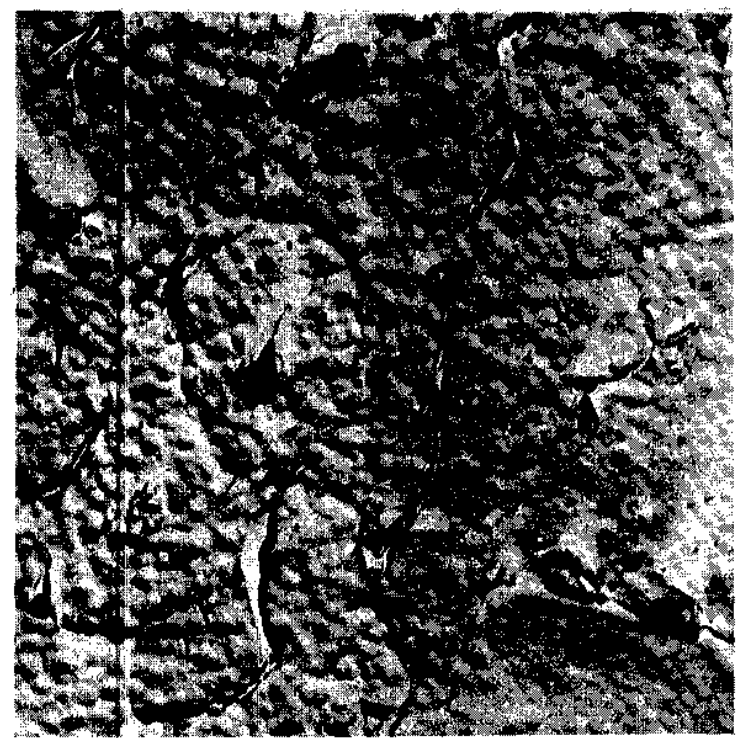

$6000 x$

As irradiated at $500^{\circ} \mathrm{C}$

Annealed 74 hr at $600^{\circ} \mathrm{C}$

FIG. 12 GAS BUBBLES PRODUCED BY POSTIRRADIATION ANNEALING $\left(74 \mathrm{hr}\right.$ a $600^{\circ} \mathrm{C}$ ) 


\section{BIBLIOGRAPHY}

1. D. F. Babcock. Heavy Water Moderated Power Reactors Progress Report. USAEC Report DP-975, E. I. du Pont de Nemours \& Co., Savannah River Laboratory, Aiken, S. C. (1965). (A I1st of the preceding reports in this series is given in the Bibliography.)

2. A. M. Huntress and D. F. Kaufman. Evaluation of Three Enriched HWCTR Driver Tubes for Irradiation at SRP. USAEC Report NMI 4379 , Nuclear Metals, Inc., Concord, Mass. (1960)

3. C. E. Lacy and E. A. Leary. Irradiation Performance of Highly Enr1ched Fuel. USAEC Report KAPI-1952, Knolls Atom1c Power Lab., Schenectady, N. Y. (1958).

4. An Evaluation of the Properties and Behavior of Zircontum Uranium AIloys. A. A. Bauer, editor. USAEC Report BMI-1350, Battelle Memorial Inst., Columbus, Oh1o (1959).

5. S. N. Buckley. Irradiat1on Growth. Report AERE-R-3674, United Kingdom Atomic Energy Author1ty, Harwe11, Berks. England (1961).

6. C. L. Angerman and W. R. McDonell. "Metallography of U - 2 wt $\%$ Zr Alloy Before and After Irradiation." Technical Papers of the Fifteenth Metallography Group Meeting, May 17-19, 1961, Savannah River Laboratory, A1ken, S. C. USAEC Report NMI-4997, p. 163, Nuclear Metals, Inc., West Concord, Mass. (1964).

7. W. V. Johnston. The Effects of Postirradiation Annealing of Uranium-Zirconium Alloys. USAEC Report KAPL-1562, Knolls Atomic Power Lab., Schenectady, N. Y. (1956). 